\title{
GREAT GRAY OWLS IN SASKATCHEWAN (1974-1983)
}

WAYNE C. HARRIS, Box 414, Raymore, Saskatchewan. S0A 3J0

I saw my first Great Gray Owl in the spring of 1974 along the east side of Montreal Lake. It was late and dark and I saw only a silhouette, and to be truthful could not be $100 \%$ certain that the two birds seen were actually Great Gray Owls. However it was sufficient to spark my interest in the species. A check of the literature at that time showed that there were very few Great Gray Owl records for Saskatchewan and that it had not been too long ago that the Great Gray Owl had been considered a rare and possibly endangered species in North America. Had it not been for the work of R.W. Nero and H.W.R. Copland in southeastern Manitoba the rare/endangered status may still have held in 1974. ${ }^{20}$ It was, however, still considered rare in Saskatchewan. Although I spent all of the summer of 1975 working and travelling in the forested areas of central Saskatchewan, I was not lucky enough to see another Great Gray Owl in spite of the hundreds of hours spent looking. It was not until September of 1975 that I, along with Sheila Lamont, encountered another Great Gray Owl. We did not see it, but the encounter remains permanently impressed in my memory, and remains more impressive than any other encounter with birds I have ever had.

We were asleep and it was the middle of the night when I heard a Great Gray Owl in my "dreams". In a semi-sleep I sat up but the calling continued. It was not a dream, but reality! I had listened to that deep, resonating hoot so many times on
Peterson's records that there could be no mistaking the call of the Great Gray Owl. I woke Sheila and we went looking. It was calling from aspen forest northwest of Little Amyot Lake. It quit calling when we moved in its direction. It did not call again that night or the next, but two nights later on 18 September we heard it again, calling from the same area. This time we did not "chase" it but lay there in the middle of the night listening to it for more than an hour until falling asleep - the ultimate in music to sleep by!

Those encounters were the beginning of my interest in Great Gray Owls and this article briefly summarizes observations collected during the past ten years.

\section{History in Saskatchewan}

In 1957 Houston summarized all records of the Great Gray Owl known to that date..$^{10}$ There was a grand total of 28 records with most of them from the 1950s. Undoubtedly due to Houston's article there were five reports published in the Blue Jay in the next two years. ${ }^{2}>111826$ The next 13 years saw only 13 sightings reported within the province, an average of one owl per year. ${ }^{9} 11141516192428$ Thus as of 1973 there were but 41 sightings recorded for all of Saskatchewan; one would have assumed that at that time Houston's quote of Edgar Jones that the Great Gray Owl appears to be following "close on the footsteps of the beautiful Whooping Crane. There 


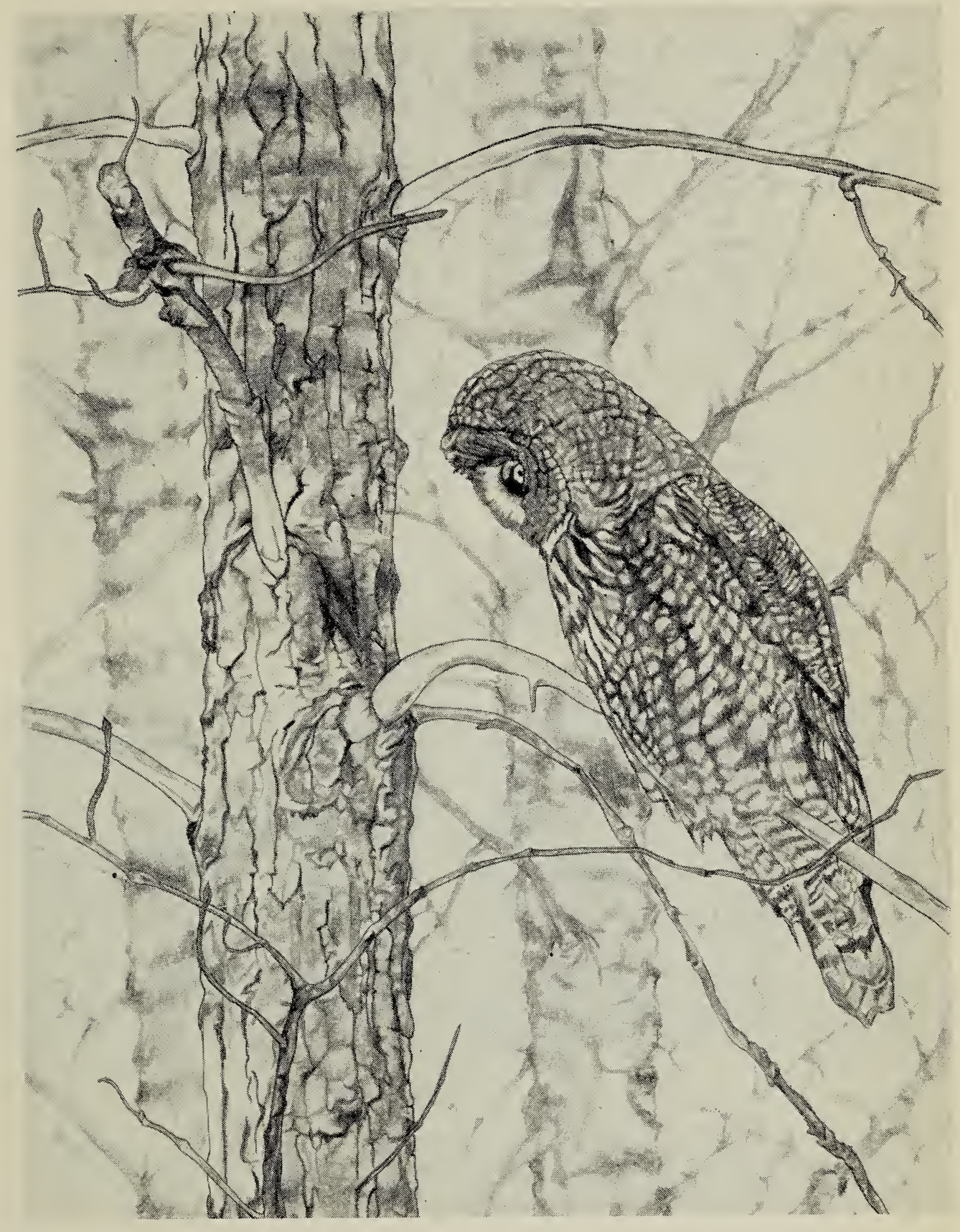

Sketch of Great Gray OwI

K. Schmuck 
is no doubt that the predations of man will eventually force the species into extinction" could in all likelihood be true. ${ }^{10}$

However the work of R.W. Nero, H.W.R. Copland and others in southeastern Manitoba and Minnesota had shown that Great Gray Owls are not as rare as historical records would indicate, and that Richardson's consideration of the species as common (in the Cumberland House area) during the period 1820-27 was still true in at least a portion of its North American range. ${ }^{20} 10$

\section{4-1983 Records}

During the ten-year period a total of 316 Saskatchewan Great Gray Owl records have been tabulated (more than 250 of these by the author). Figure 1 shows the distribution of these records in the province. The concentration in the east-central part of the province is most likely a bias due to time spent searching that area rather than showing actual greater abundance. The highest one-day count was 27 February 1982 when Arnold Nijssen and the author saw four between Nipawin and Cumberland House. That same area produced 23 sightings during an 18-day period 10 February to 27 February 1982, the highest concentration located to date.

The majority of the records are from the period November through April with virtually no sightings for June through August. This is not due to more time being spent searching during fall and winter months. In fact, the converse is true. More than $75 \%$ of the time the author spent travelling in the forest was during the June to August period. Consequently Great Gray Owls are simply not seen during the summer months when they are presumably busy raising young, and are less vocal.

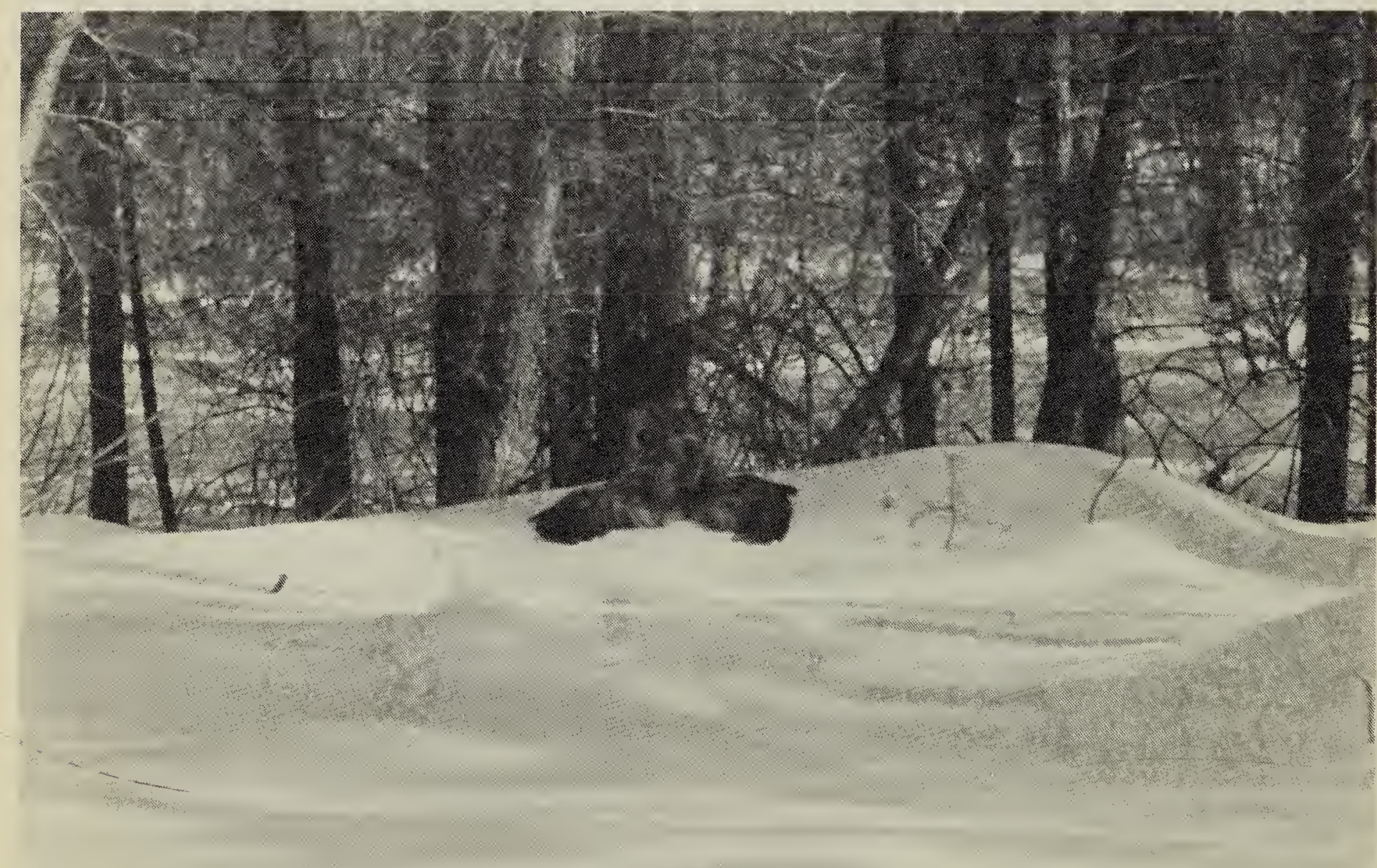




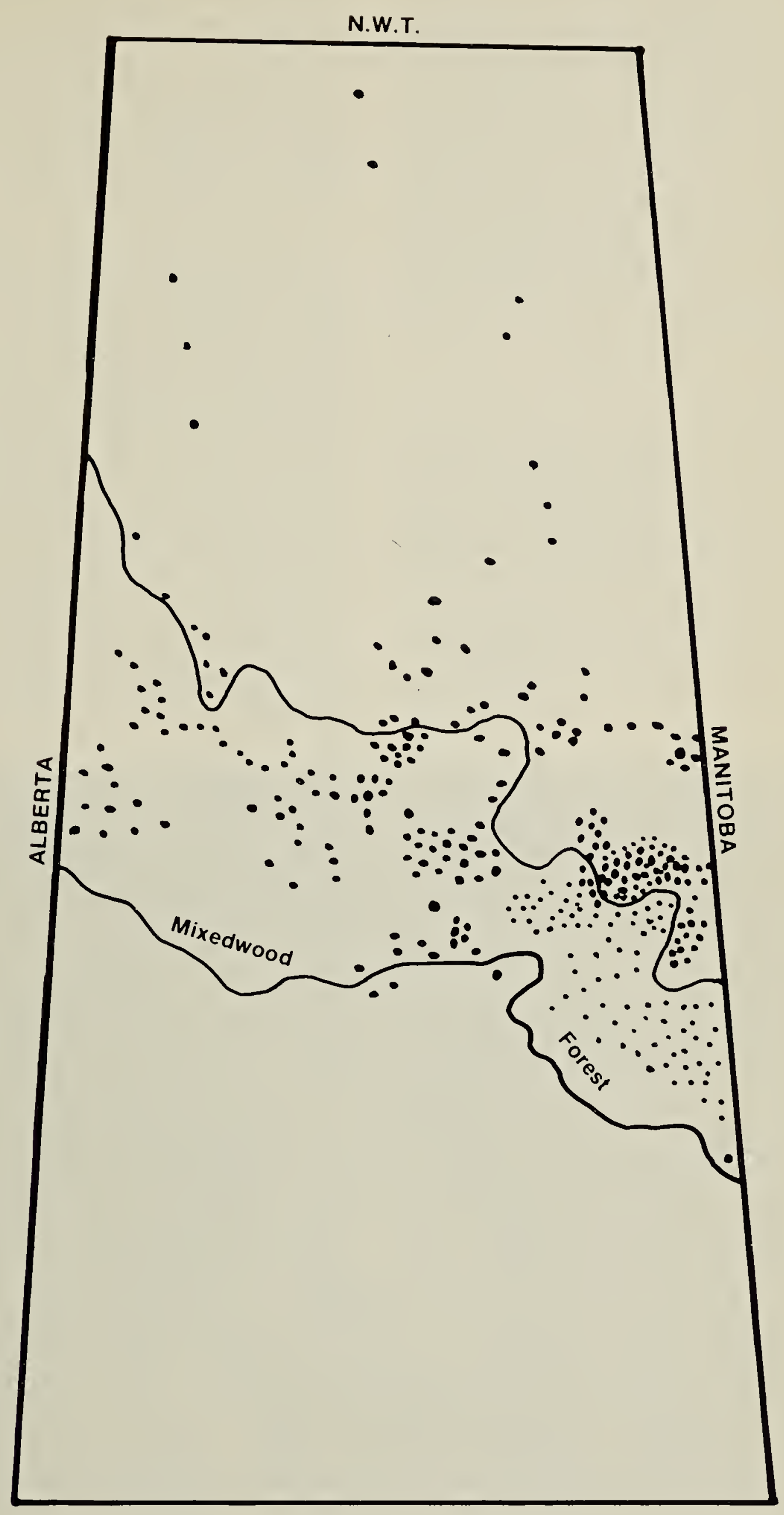

Figure 1. Distribution of Great Great Owl sightings in Saskatchewan. 
Most of the owls were actually seen but many of the March-April-May records were heard only. During this period surveys were carried out along roads in forested areas with regular stops to listen for birds. Imitations of calls were regularly used to solicit calling from all of the forest owl species (Great Horned, Great Gray, Barred, Boreal and Saw-whet). Using this method many of the roads were covered in the southern boreal forest of Saskatchewan.

\section{Distribution}

AREAL: The Great Gray Owl is found from the northern edge of the Aspen Parkland northward probably to the Northwest Territories, although there are no records for extreme northern Saskatchewan. Spring census would indicate that Great Grays are most common in the northern Mixedwood Forest Region. ${ }^{8}$ Although
Great Horned Owls are more common than Great Grays in the southern Mixedwood Region, they are virtually equal in the northern Mixedwood. This trend holds true throughout the year with the exception of the Cumberland Lowlands where Great Grays can be more common during the winter months (i.e. 1982).

SEASONAL: Figure 2 illustrates the seasonality of Great Gray Owl sightings. Owls are much more conspicuous during late winter - early spring, undoubtedly due to the ease of obtaining food along roads. February is by far the best month to see Great Gray Owls, while late March and April is the best time to hear owls. Great Gray Owls are virtually impossible to find during July and August when adults are feeding young near nest sites and young are not yet mobile enough to reach roadways to be seen. Great Grays begin to appear

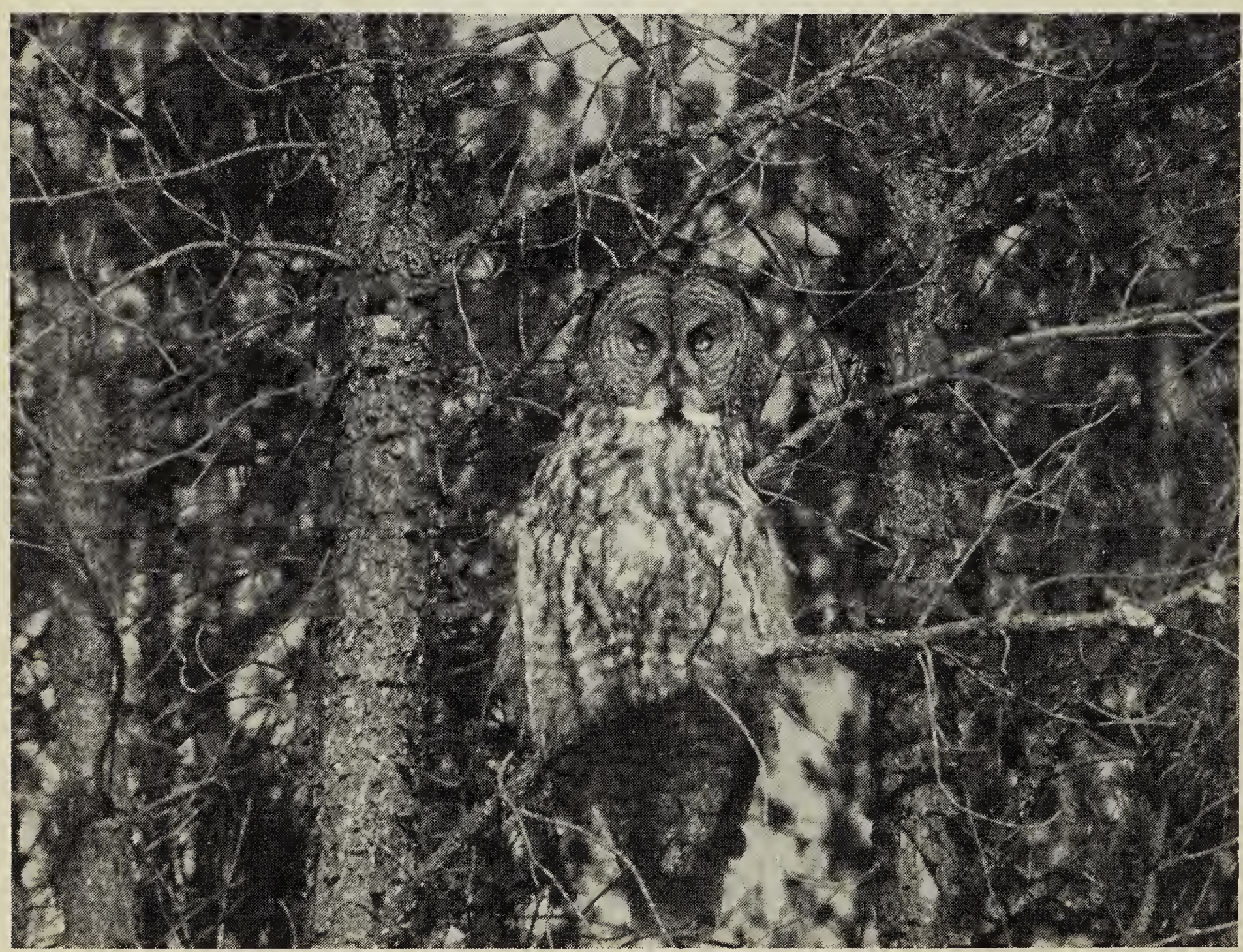




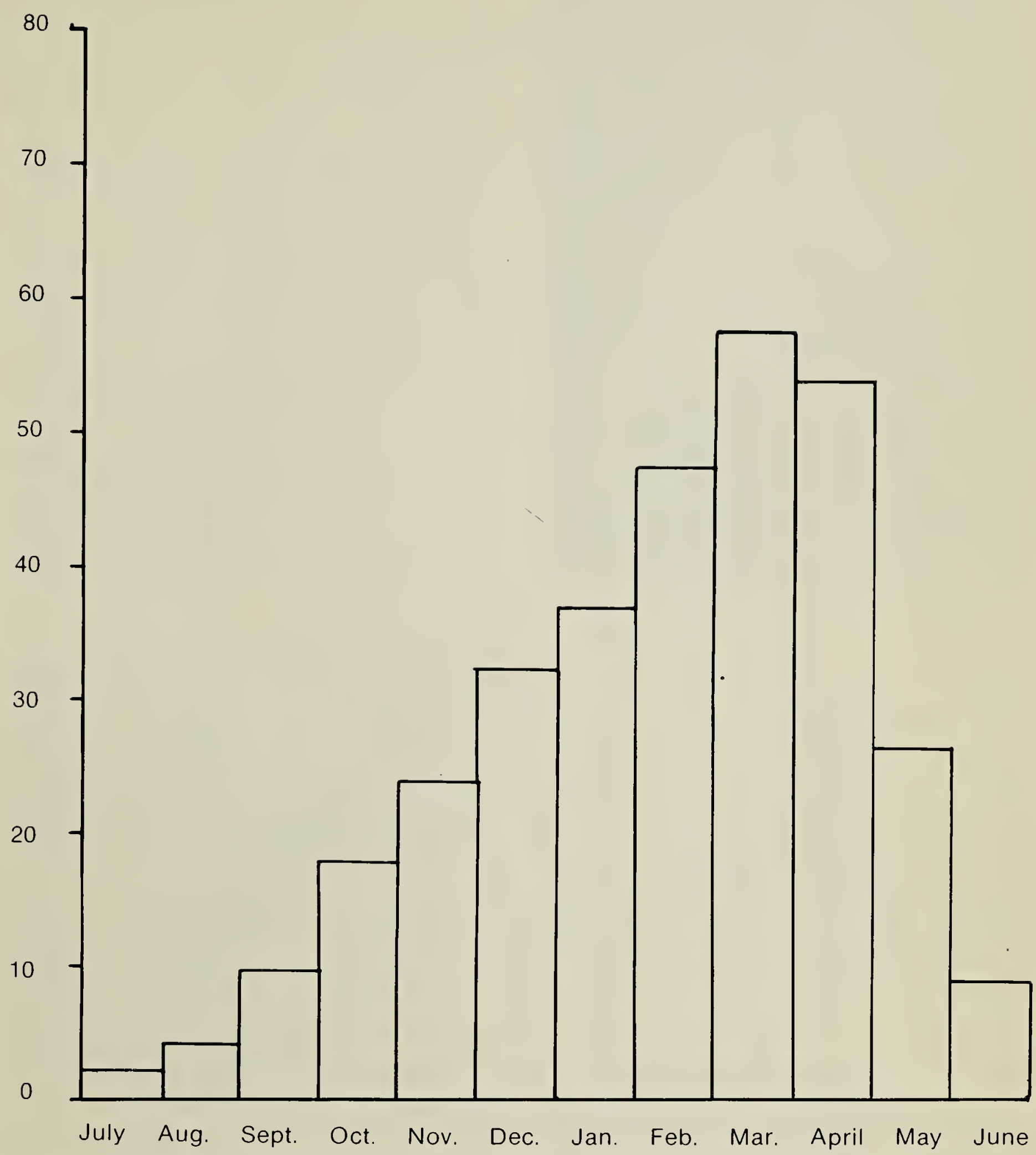

Figure 2. Monthly totals of Great Gray Ow/ sightings in Saskatchewan.

along roadsides again in October.

\section{Habitat}

Areas inhabited by Great Gray Owls are quite varied during the nonbreeding season. They are found in a variety of upland forest communities from aspen to pine forest. There does appear to be a slight preference to- wards forests which have a mixed deciduous - coniferous (aspen spruce) component. During the breeding season a strong preference is shown to areas which have Tamarack and Black Spruce present. Although the birds may not be specifically in this "bog" habitat, they are usually nearby. 


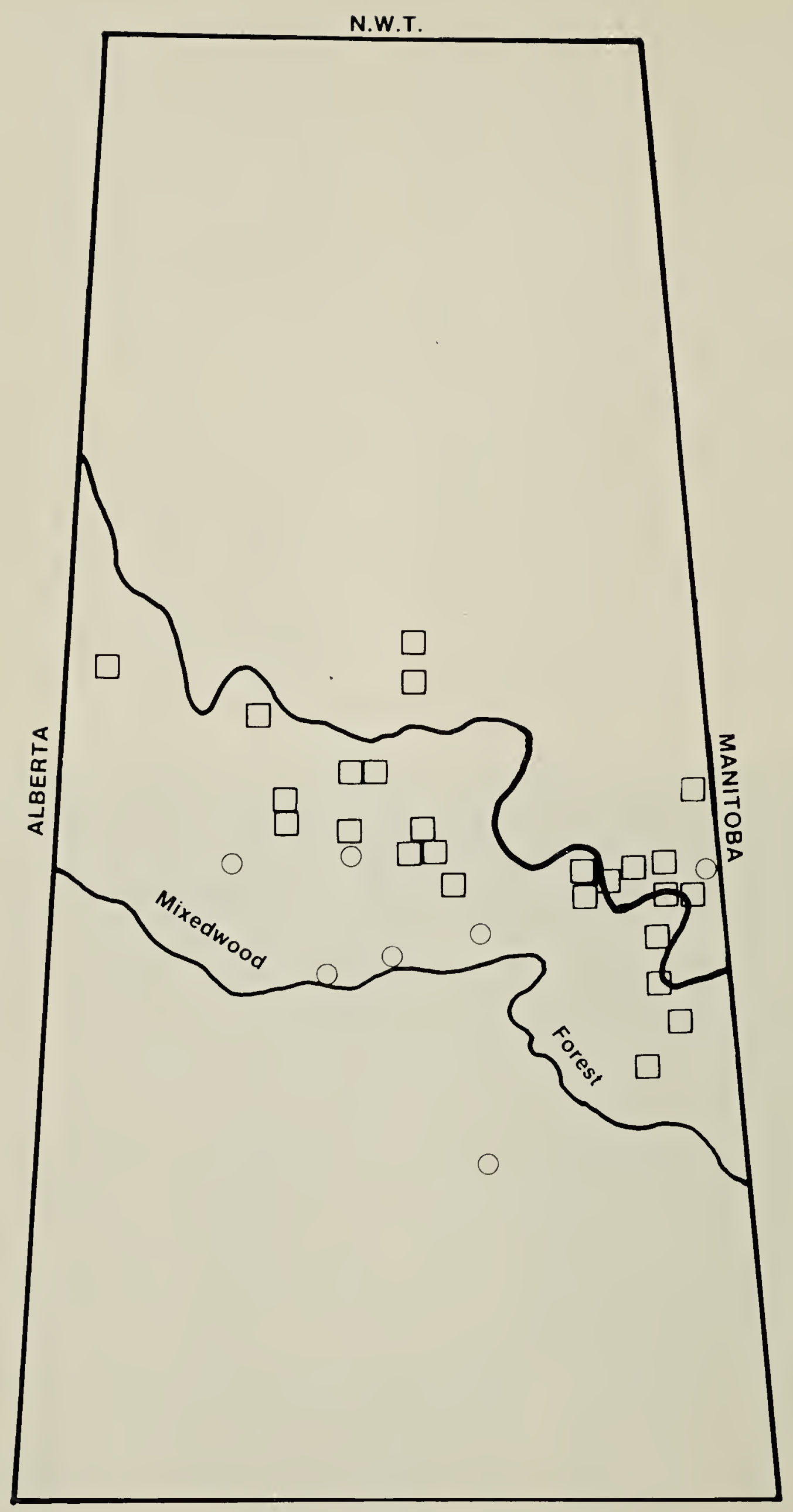

Figure 3. Breeding records for Great Gray Ow/s in Saskatchewan. O Nest record or adults with young. $\square$ Territorial pair. 


\section{Breeding Records}

Houston and Wylie list the five known nest records for Saskatchewan. ${ }^{12}$ They do not consider those records which include young of the year or territorial pairs. The five known nests are plotted in Figure 3 along with the "unconfirmed" breeding records in an attempt to depict the known breeding range in Saskatchewan. These "unconfirmed" breeding records include fledged young still accompanied by adults and hooting adults during April and May. The breeding range is confined to the forested portions of the province. The species is more common during the breeding season in the northern portions of the Mixedwood Forest than in the southern portion. It is in this area that more Black Spruce occurs.

A review of the habitat of the 27 suspected breeding locations shows that the Great Gray Owl is very closely tied to Black Spruce - Tamarack forested wetlands. Each location of suspected breeding owls was plotted on $1: 12,500$ forest inventory maps to ascertain vegetation patterns. In 25 of the 27 locations a Black Spruce Tamarack wetland was located within $500 \mathrm{~m}$ of the plotted location of the suspected territory. In most cases, however, the birds were calling from forested uplands adjacent to the bogs, rather than from the bogs themselves.

\section{Summary}

Although the Saskatchewan observations are few in number compared to Manitoba, the data indicates that Great Gray Owls are not as rare in Saskatchewan as previously thought. Great Gray Owls are, at the least, uncommon permanent residents of forested Saskatchewan, and may be the most common owl of the northern Mixedwood Forest. The preference for bogs is confirmed in Saskatchewan, following patterns observed

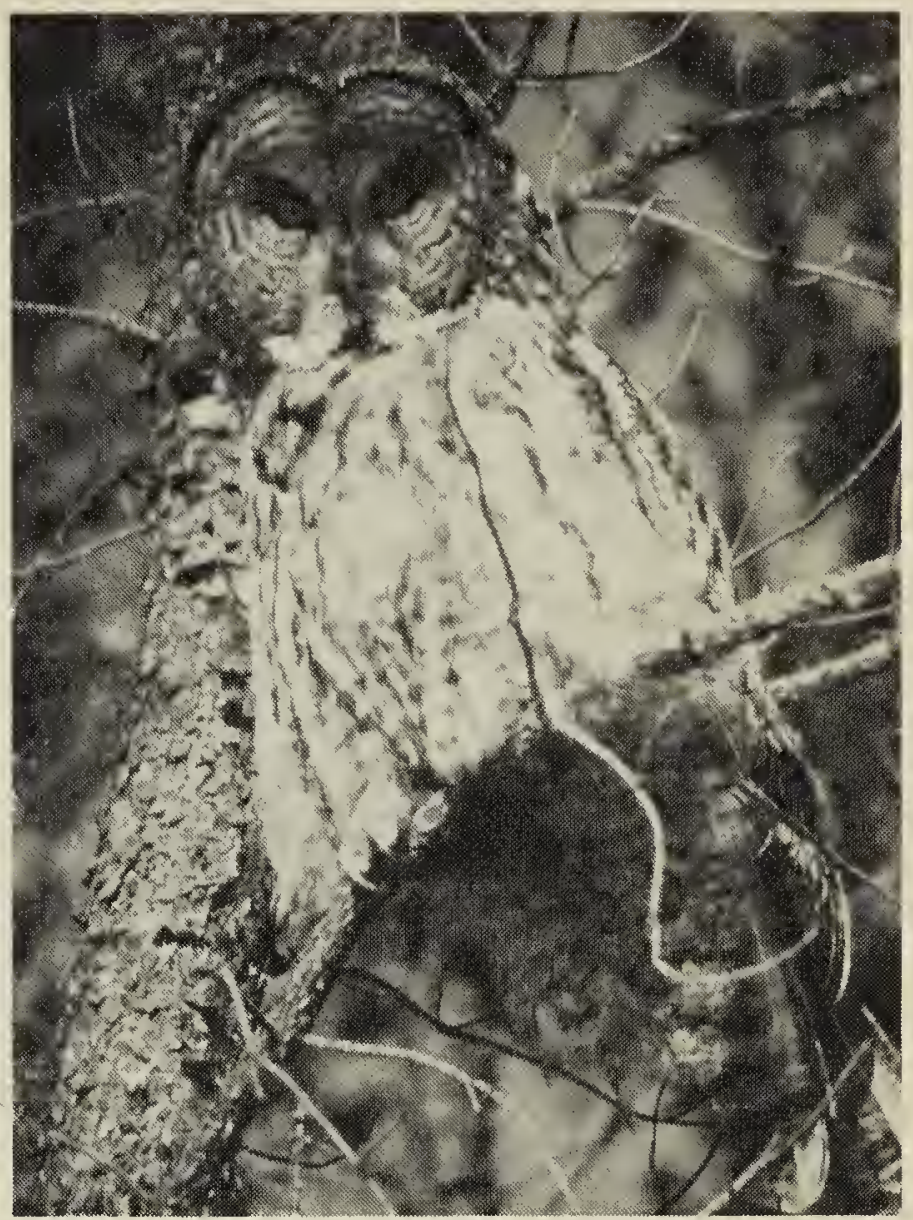

Great Gray Ow/s are sometimes

exceedingly tame Wayne C. Harris

in Manitoba. The tabulation of data indicates that Great Gray Owls are most frequently seen during winter and early spring, with February through April being the months of prime time. Work concentrating in east-central Saskatchewan has proven that the Squaw Rapids - Cumberland House area is by far the best area in the province to find Great Gray Owls at any time of year.

\section{Acknowledgements}

I would like to express my appreciation to those who accompanied me on trips in search of Great Gray Owls, in particular Carman Dodge, Sheila Lamont and Richard Miller. Also those who responded to my request for information, namely Stan Shadick, Al Smith, Oliver Johnson, Rodney Froc, Don Weidl, Frank Switzer and Wayne Renaud. And lastly Bob Nero, who supplied information and whose phenomenal work in Manitoba provides incentive to keep looking in Saskatchewan. 
1 ANAKA, WILLIAM. 1961. Great Gray OwI at Spirit Lake. Blue Jay 19(4):174.

2 BAINES, ELWIN. 1958. Summer record of Great Gray Owl. Blue Jay 16(4):155.

${ }^{3}$ BAINES, K.E. 1954. It is a foolish bird. Blue Jay 12(2):20.

${ }^{4}$ BARD, FRED G. 1947. Museum notes. Blue Jay 6(1):9-12.

${ }^{5}$ BELCHER, MARGARET. 1982. 40th annual Saskatchewan Christmas bird count - 1981. Blue Jay 40(1):17-29.

${ }^{6}$ CARMICHAEL, L.T. 1954. Protection of hawks and owls. Blue Jay 12(2):19.

7 FRANCIS, C. STUART. 1960. Nature notes from Spruce Dale Farm. Blue Jay $18(1): 3$

${ }^{8}$ HARRIS, W.C., A. KABZEMS, A.L. KOSOWAN, G.A. PADBURY and J.S. ROWE. 1983. Ecological regions of Saskatchewan. Technical Bulletin No. 10. Forestry Div., Sask. Parks and Renewable Resources.

${ }^{9}$ HARSTAD, WALLY. 1965. Great Gray Owl. Animals 6(12):344.

${ }^{10}$ HOUSTON, C.S. 1957. The Great Gray Owl in Saskatchewan. Blue Jay 15(3):150-153.

11 1962. Further Great Gray Owl records. Blue Jay 20(1):4.

12 HOUSTON, C.S. and K.A. WYLIE. 1984. Fifth documented Great Gray Owl nest in Saskatchewan. Blue Jay 42(3):161-164.

${ }^{13}$ HOUSTON, DR. STUART. 1956. Great Gray Owl banded at Saskatoon. Blue Jay $14(1): 11$

${ }^{14}$ HOUSTON, MARY I. 1969. Twentyseventh annual Saskatchewan Christmas bird count, 1968. Blue Jay $27(2): 12-17$.

1972. Thirtieth annual Saskatchewan Christmas bird count. 1971. Blue Jay 30(2):18-23.
1974. 32 nd annual Saskatchewan Christmas bird count, 1973. Blue Jay 32(2):90-96.

17

1981. 39th annual Saskatchewan Christmas bird count, 1980. Blue Jay 39(1):13-24.

${ }^{18}$ LAW, C. 1960. The Great Gray Owl of the woodlands. Blue Jay 18(1):14-16.

19 NERO, R.W. 1965. Some interesting bird records for central Saskatchewan. Blue Jay 23(3):133.

20 NERO, R.W. 1969. The status of the Great Gray Owl in Manitoba, with special reference to the 1968-69 influx. Blue Jay 27(4):191-209.

${ }^{21}$ NERO, R.W. 1980. The Great Gray Owl: phantom of the northern forest. Smithsonian Institution Press, Washington, D.C. $167 \mathrm{pp}$.

22 NERO, R.W., H.W.R. COPLAND and J. MEZIBROSKI. 1984. The Great Gray Owl in Manitoba, 1968-83. Blue Jay 42(3):130-151.

${ }^{23}$ OEMING, A.F. 1955. A preliminary study of the Great Gray Owl (Scotiaptex nebulosa Forster) in Alberta with observations on some other species of owls. M. Sc. thesis, U. of Alberta, Edmonton.

${ }^{24}$ SEPT, DUANE. 1976. Great Gray Owl and Whip-poor-will in Prince Albert National Park. Blue Jay 34(3):164165.

${ }^{25}$ SHAW, C.C. 1947. Bird notes. Blue Jay $6(1): 2-5$.

${ }^{26}$ STREET, MAURICE G. 1960. Further reports of Great Gray Owls. Blue Jay $18(1): 16$.

27 SYMONS, R.D. 1967. Hours and the birds, a Saskatchewan record. U of Toronto Press. 224 pp.

${ }^{28}$ WADE, DOUGLAS E. and DOROTHYR. WADE. 1962. Some bird observations along the La Ronge-Churchill River and Hanson Lake Roads. Blue Jay 20(1):10-11. 